\title{
Narseh, Armenia, And the Paikuli Inscription
}

\author{
Carlo G. Cereti \\ iD http:/orcid.org/0000-0002-8442-9554 \\ Sapienza University of Rome
}

\begin{abstract}
Narseh son of Šābuhr I reigned from 293 to 302, once he had won the dynastic war that saw him opposing his grand-nephew, Wahrām III, he narrated the events in the great Paikuli inscription, which also contains the names of a long list of nobles and magnates, who paid obeisance to the new king. In Šābuhr's inscription at Naqš-i Rustam Narseh bore the title of « King of Hindestān, Sagestān and Tūrān up to the seashore," while later, likely under either Ohrmazd I or Wahrām I, he became King of the Armenians and stayed in office until 293, when he moved south to challenge his nephew's right to the crown. Crossing the lower ranges of the Zagros mountains on his way to Mesopotamia, Narseh met the nobles loyal to his cause near the pass of Paikuli, about one hundred kilometres south of the modern city of Sulaimaniya. Recent archaeological excavations on the site have brought to light a number of new inscribed blocks that allow for a better understanding of the structure of the monument. In this paper the passages relative to Armenia will be presented and discussed, together with those containing the name of the goddess Anāhīd, whose cult was widely spread in Armenia.
\end{abstract}

Keywords: Armenia, Anāhitā, Narseh, Paikuli inscription, Sasanian Empire.

In Šābuhr's inscription at the Ka 'aba-i Zartusht (ŠKZ) Ormazd-Ardašīr holds the title of "Great King of the Armenians" (wuzurg armenān $̌ \bar{s} \bar{a} h$ ), ruling the lands conquered by his father in the 252/253 military campaigns. In 260/262, when ŠKZ was written ${ }^{1}$ Narseh was "King of Hind(estān), Sagestān and Tūrān up to the seashore" a title that he likely held until the death of his father, when Ormazd rose to the imperial throne, only to reign for a brief one year and leave the crown to Wahrām I, under whose reign Mānī was sentenced to death, marking an abrupt turnabout in Sasanian religious policy. The sources do not tell us when precisely Narseh became King of the Armenians, however chances are that he either immediately followed Ormazd in this position ${ }^{2}$ or that he

1 Huyse 1999, I: 10-14.

2 Chaumont 1968; Chaumont 1987, 426. 
obtained the office when Wahrām I, the eldest of Šābuhr's sons, rose to power. ${ }^{3}$ On the other hand, we know from his Paikuli inscription that he held authority over the Iranian part of Armenia until 293, when a part of the Sasanian nobility invited him to contest the throne.

Once he had decided to throw down the gauntlet and challenge his nephew Wahrām III for the Sasanian throne, Narseh moved southwards from Armenia, crossing the Qaradagh range at Paikuli where he ordered his inscription to be written on the outer curtain of a monument built to celebrate his victory in the dynastic war. Qaradagh is the last mountain chain of any relevance that one crosses coming from Shahrazur when heading towards the Mesopotamian plain and the area of Ctesiphon; the pass of Paikuli therefore represents an important border post of the historical region of Asürestān. ${ }^{4}$ Here, before moving towards the metropolis, Narseh waited for the nobles who came to the regional frontier to pay obeisance to the new sovereign.

\section{Armenia in Narseh's Paikuli Inscription}

The Paikuli inscription presents a few occurrences of the geographical name Armenia and mentions more than once that Narseh was the "king of the Armenians"; as we have already seen, before becoming King of Kings he had been King of the Sakas (ŠKZ) and then King of the Armenians (Paikuli). Strikingly no passage in the inscription of Paikuli says that Narseh was the "Great King of the Armenians," this being the title carried by Ormazd-Ardašīr in ŠKZ. The name of the goddess Anāhīd twice appears in this inscription and we know that her worship was particularly important in Armenia.

The toponym MP 'Imny Pth. 'rmny, /Armen/ "Armenia" comes forth in several passages of the Paikuli inscription, ${ }^{5}$ the same being true for the ethnonym MP 'Imn'n Pth / 'rmnyn/ "Armenians." The former is used to indicate the land Armenia, while the latter is only found in the syntagma 'Imn'n/'rmnyn MLKA in the meaning "King of the Armenians." The theonym Anāhīd (MP 'nhyt; Pth. 'nhtyE) comes forth twice, once as the name of the goddess herself, Anāhìd Bānūg (Anāhīd the Lady) and once in the name of the monument itself: Pérōz-Anāhìd-Narseh. Another important piece of information about Armenian history contained in our inscription is the mention of the name of King Tirdād (tyldt MLKA), often identified with Tiridates III, ${ }^{6}$ though Kettenhofen ${ }^{7}$ has clearly shown that we do not have enough information to positively identify this king with any of the known Tiridates, who, in the opinion of the German scholar, may well

3 Weber 2012, 153.

4 Cereti - Terribili - Tilia 2015; Cereti - Terribili 2012.

5 The Paikuli inscription is quoted according to Humbach - Skjærvø 1979-1983 to which passages from the new blocks published in Cereti - Terribili 2014 or found in the latest archaeological campaigns (see CeretiColliva - Terribili 2019) have been added.

6 I.a. Humbach-Skjærvø 1979-1983, 3.3, 126.

7 Kettenhofen 1995, esp. 144-168. 
have been an older relative of Tiridates the Great, under whose reign Armenia became Christian. ${ }^{8}$

After a short introduction listing Narseh's titles, one comes to an important passage preserving the name of the monument; the Parthian version of this passage was first read on block a 12 published in 2014, ${ }^{9}$ while the Middle Persian one is found on A12, ${ }^{10}$ discovered in the 2018 season. ${ }^{11}$ Thereafter, the main body of the inscription starts off by saying that he was the King of the Armenians and dwelt in Armenia until Wahnām son of Tatrus proclaim Wahrām III King of Kings:

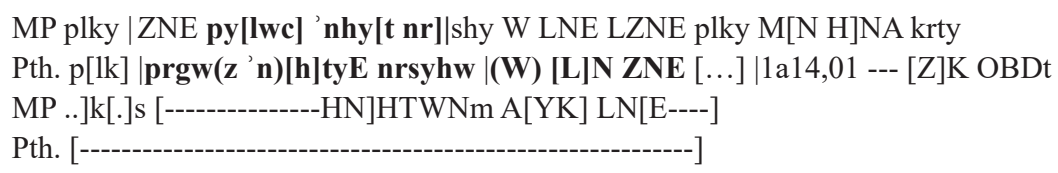

$\S 2$. This is the monument of Pērōz-Anāhīd-Narseh ${ }^{12}$ and we made this monument because ... and placed ... that We ...

MP [LNE?] 'Imn'n ML[KA] HWYTNm W '1mny [phl[sty HWEm

Pth. [-

MP -----|-------------------hwcst]n OBLWN W whwn'm |A8,02ZY ttlws[(')n

Pth. ----------------------hw] (z)stn HBDYWd W whyn'm ME ttrwsn

$\S 3$. We were King of the Armenians. And we dwelt in Armenia (until . . in) Khuzistan passed away and Wahnām son of Tatrus ...

The two blocks, Middle Persian and Parthian, discovered in the campaigns led by the Italian archaeological mission to Iraqi Kurdistan reveal the name given by Narseh to the monument he erected to proclaim his victory in the dynastic war. Pérōz-Anāhìd-Narseh is a name which confirms the important role played by the goddess in the royal ideology of early Sasanian times. On the whole, the formula employed can be compared to the dedication in the so-called Nokonzog Bactrian inscription. ${ }^{13}$

A number of notables, Persians and Parthians, who were at the border watch-post of Asōrestān, thought that Narseh would be a much better candidate for the Crown and asked him to move from Armenia to Ërānšahr:

MP s's' [nkn ?] W hm'ky štr GBR[An '1](m)[n']n MLK[A mhsty W p'ls]wmy

Pth -----------------]GBR(A) 'rmn(y)n MLK(A) msyšt W prtr

8 No new material on the passage where King Tìrdād is mentioned has come to light ( $\$ 92$ of the Paikuli inscription, see Humbach - Skjærvø 1979-1983, 3.1,71), nor is there to the best of my knowledge any new evidence leading to a better understanding of his historical identity, therefore this character will not be further discussed here.

9 Cereti-Terribili 2014, 355, 357.

10 Middle Persian blocks are recorded in upper case letters, and Parthian ones in lower case.

11 Cereti-Colliva-Terribili 2019, 7.

12 The compound Pērōz-Anāhìd-Narseh, should be compared with Wahrām's well known epithet in Kerdīr's inscriptions: Bōxt-ruwān-Wahrām, for which I agree with MacKenzie 1989, 63, rather than Grenet 1990, 90-91, followed by Gignoux, 1991, 69, note 134. Pērōz-Anāhīd-Narseh is probably a possessive compound with the approximate meaning "Narseh with a victorius Anāhīd," i.e. "Narseh victorious by the grace of Anāhīd," and was the name of the monument itself, a name which would underline the importance of this deity in securing victory to the legitimate heir of the dynasty. See further Cereti - Terribili 2014, 357 .

13 See Cereti - Terribili 2014, 358, note 42. 
$\S 13 . .$. (of) the Sasanians and (of) the men of the entire country the King of the Armenians is the greatest and the best.

MP MLKAn MLKA PWN krpkyhy MN 'Imny 'wlwny OL 'yr' nštry 'yw whycyt Pth MLKYN ML[KA pt]y [--------------------]PNE-[rwn O]L 'ry'nhš(tr)[------

§18. May the King of Kings graciously move from Armenia hither to Ērānšahr . . .

Narseh answered the plead of the Princes, Grandees, Householders and Nobles, and in the name of Ohrmazd, all the Gods and Anāhīd, moved southwards to reach the political and economic centre of the Sasanian Empire:

MP W LNE AYK ZK prwltky H(ZY)[TNm ? W PW]N 'whlmzdy W wsp'n yzd'n

Pth [W] (LN AYK L)Hw prw(rt)k HZYWm W pty 'whrmzd (W wy)spn y'ztn

MP W 'nhyt ZY MROTA ŠM M[N] 'lm(n)y OL 'yr' nštry lwny whycwmy

Pth $\mathrm{W}$ 'nh[t]yE <-> MRATY ŠME MN 'rmny OL 'yr'n-[h]štr [---- ------]w[m?]

$\S 19$. And when We saw that letter, then in the name of Ohrmazd and all the gods and Anāhīd, the Lady, We moved from Armenia towards Ērānšahr.

Armenia is again mentioned in paragraph 33, in a passage describing an episode of the dynastic confrontation:

MP W (w)lhl'(n) ZY (s)[k'n MLKA

] (Z)Y ttrws[(')n ------] M[NW ?

Pth W (wr)[-----------------------]W whyn'm <-> ttrwsn LHw ME wty W

MP OL?]E MNW whwn'm hms[hwny W] hdybl [------------------OŠMEN]d

Pth [------------ ] hmyshwny W 'dywr HWYEnt AYK AŠMOYWnt

MP A(YK) [LN](E) M(N) 'Imny 'yr'n-štry lwny wh[s]ty HWEm [W ?] 'yr'nš[try

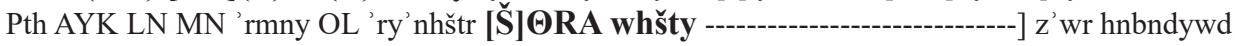

MP ------ h]west[n OL ? ']lm[ny lwny ? SG]YTNd

Pth. W MN hwz[stn -------------------------]

$\S$ 33. And Warahrān, [King] of Sakas, and Wahnām, son of Tatrus, and the bad ones (?) and those (?) who were Wahnām's partisans and helpers - when they heard that We had set out from Armenia towards Ērānšahr and had mobilized an army of Ėrānšahr (?) - then they went from Xūzestān [towards] Armenia (?).

The blocks published by Cereti and Terribili in 2014 allow for a better understanding of the second part of $\S 34$, where the king of the Armenians is again mentioned:

MP whwn'm P[WN| $\left.{ }^{D 8,01} \mathrm{NP}\right] \mathrm{S} E \mathrm{E}\left[{ }^{\prime} t\right]$ wkyhy[-

Pth. [--wh]y'n[m] pty [N]P[ŠE] y'ts'rpy 'trw[pr]nbg

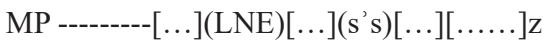

Pth. ME myšs $n$ [M]LKA [...]('n)[...](M)[... ' $\mathbf{r}(\mathbf{m}) \mathbf{n}[\mathbf{y}](\mathbf{n})[\mathbf{M}] \mathbf{L}(\mathbf{K})[\mathbf{A}]$

MP -----------------------------------------|D14,01(M)LK(A)|D15,01

Pth. OL] pry’t YBOEd W myšn MLKA ptgm [ŠLHWd AYK ?]

$\S$ 34. Wahnām by his own sorcery sought help from Ādurfarrbay King of Mēšān (against) Us . . .

Sāsān (?) . . . the King of Armenians, . . . and he sent a message to the King of Mēšān, that: . . .

Taken together with the following paragraph, this passage may suggest that the "Great Diadem" was offered to Ādurfarrbay, King of Mēšān while the King of the Armenians was far away. 
MP [myšs n? ML]KA pr['c] ('y)w YA(T)[WN|D2,02 $]$ t A[H]R[N] HT s[k']| MLKA lsyk ADYNc

Pth [-------] MLKA prhš hyp ATYEt AHRN 'k skn MLKA 'šnht 'dynš

MP myš n MLKA HNA [----------------------dyd']ymy myš n MLKA YHBWN

Pth myšn MLKA ZK [[....šw] $]$ gwn (Z)NE RBA ------------] MLKA YNTNWn

MP OD 'Imn'n MLKA LHYK 'nd[..]n

Pth HN 'rmnyn [--------------------------]

§ 35. May the King [of Měšān?] come forth. If another is the page of the King of the Sakas, then the King of Mēšān that [... just as I shall give this Great Diadem to the King of Mēšān until the King of the Armenians . . . is far away.

Summing up, Armenia is mentioned in the Paikuli inscription more than in any other epigraphic text dating to the Sasanian period. This is not surprising, since Narseh was the sovereign of Sasanian Armenia under Wahrām II. According to our text, at the time of Wahrām's death, Narseh was the King of the Armenians and dwelled in Armenia (§3) and the King of the Armenians was the greatest and the best of all Sasanians and of all men of Érānšahr (§ 13). The Princes, the Hargbed, the Grandees and the Nobles of the country invited the King of Kings to move from Armenia to Éranš̌ahr to take back the throne, and Narseh promptly accepted the invitation (§§ 18-19). Wahnām son of Tatrus and Wahrām King of the Sakas (Wahrām III) moved against Narseh, and someone offered the Great Diadem to Ādurfarrbay, King of Mēšān ${ }^{14}$ while the King of the Armenians was far away ( $\S \S 33-35)$. Twice in the inscription the name of the goddess Anāhīd turns up. Though the Sasanians were the hereditary guardians of the temple of this deity at Istakhr, no other king, except for the Achaemenian Artaxerxes II, mentions her name in his inscriptions; even more interesting, the name of the Paikuli monument, Pérōz-Anāhīd-Narseh, shows that the Sasanian sovereign thought that Anāhīd assisted him in obtaining victory, considering her to be a sort of Iranian Nike.

\section{Armenia in Middle Persian Inscriptions and Glyptics}

The toponym 'Imny/' rmny /armen/ is well attested in Sasanian primary sources. The name Armenia is found on the impressions of the seals belonging to two different

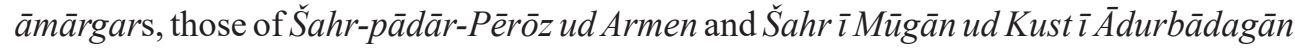
Bāzāha ud Armen; on the impression of the seal of one Zarrbed carrying the toponyms of Armen ud Ardān [Arrān]ud Wirōzān ud Sīgān ud Marz ì Nǐšawān; and on the impressions of the seals belonging to two Gund $\bar{\imath}$ kadag-xwadāyan framādār, both carrying the

14 In ŠKZ a fire is dedicated to the soul and fame of Šābuhr king of Mēšān, son of Šābuhr I ( $\$ 34$ any $\bar{a}$ dur 1 Husraw-Šābuhr nām, pad Šābuhr ì Mēšān šāh ì amā pusar ruwān ud pannām, Huyse 1999, II: 47). In that inscription Šābuhr King of Mēšān comes immediately after Ohrmazd-Ardašīr Great King of Armenia and before Narseh, King of Hindestān, Sagestān and Turān. In the other list, naming a wider number of members of the Sasanian family, found in ŠKZ § 36 Šābuhr comes immediately after Wahrām, King of Gēlān and before Ohrmazd-Ardašĩr. Therefore, he seems to be at the same time the second son of Šãbuhr I, after the eldest, Wahrām, and the second in line for the throne, after Ohrmazd-Ardašīr. This shows that the Kingdom of Mēšān was likely to be a fief of the Sasanian family and that Ādurfarrbay may have been an influent member of the ruling House to whom someone (Wahnām?) offered the Crown. 
name of Armen. ${ }^{15}$ Quite interestingly, the offices of Zarrbed and Gund $\bar{\imath}$ kadag-xwadāyan framādār are only attested for jurisdictions including the toponym Armen, ${ }^{16}$ the latter carrying this toponym alone. The position of supervisor of the gold mines is attested also by Armenian sources, ${ }^{17}$ while the office of Gund $\bar{\imath}$ kadag-xwadāyān framādār may well find a close parallel in the Armenian tradition, as has been convincingly suggested by Nina Garsoiän, who considers it to be a military title indicating leadership of the troops of the Armenian tanutērs, the Lords of the Houses (MP kadag-xwadāy) specifically attested for the Armenian prince Smbat Bagratuni, a contemporary of Husraw II. ${ }^{18}$

The geographical name Armen is also attested in other inscriptions dating to the early Sasanian period, where it indicates a province ruled by the King of Kings, but not belonging to Ėrānšahr itself. Other than in the passages from the Paikuli inscription that have been presented above, the toponym comes forth once in the list of countries at the beginning of $\breve{S} \bar{a} b u h r$ 's inscription at the Ka'aba-i Zartusht (ŠKKZ) and once in Kerdīr's narration of the events that he had witnessed in his long ecclesiastic career.

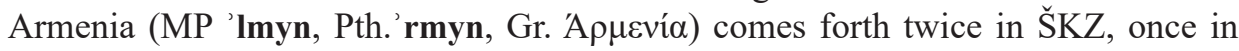
a long passage listing the provinces of the Empire, including a number of toponyms belonging to the Caucasian and sub-Caucasian area of Sasanian dominions, showing some coherence with the information provided by administrative glyptics and once in a passage explaining the cause of the war between Iran and Rome:

§ 2. ...ud dārām [šahr P]ārs, *[Par]Aaw, Xūzestān, Mēšān, A[sūrestān, Nōdšìragān, Arbāyes]tān, $\bar{A} d u[r] b \bar{a} d e g a ̄ n$, Armin, Wiržān, Sīgān, Ardān, Balāsagān yad frax̌̌ ō Kaf kōf ud Alānān bar, ud hamag Padišxwār kōf...

§ 2. ---und besitze die Länder Persis, Parthien, Xūzestān, Mēšān, Asūrestān, Nōdš̄iragān (= Adiabene), Arbāyestān, Aserbeidschan, Armenien, Wiržān (= Iberien), Sīgān, Albanien, Balāsagān, bis hin zu Kaukasus und (zum) Alanen Tor, und die ganze Elburzkette... ${ }^{19}$

§ 9. ud Kēsar bid druxt ō Armin winās kerd, ud amā abar Frōmāȳ̄n šahr wihišt ahēm, ud Frōmāȳ̄n zāwar 60.000 pad Bēbāliš ōžad;

$\S 9$. Und wiederum log der Kaiser (und) tat Armenien Unrecht; und Wir stießen gegen das Reich der Römer vor, und 60.000 (Mann) von der (Heeres)macht der Römer (wurde) in Barbalissos getotet; ${ }^{20}$

15 Gyselen 2019, 44-45.

16 Gyselen 2019, 281, 322.

17 Chaumont $1985,433$.

18 Garsoïan 2003, who concludes: “Ainsi, la possibilité d'un rapprochement entre les données des documents arméniens et le sceau sassanide nouvellement publié qui les complète, rehausse non seulement la valeur de ce dernier, mais nous fournit, à travers une coïncidence malheureusement trop rare mais pourtant souvent fructueuse entre les sources perses et arméniennes, l'explication possible d'un titre arménien peu compréhensible sans son appui."

19 Huyse 1999, I: 22-23. The passage is taken from the Parthian version, since the Middle Persian presents here a large lacuna, the Greek version confirms the readings proposed by the author. The Caucasian countries listed here are likely those conquered by Šăbuhr in the campaigns he led in the region in the years 252-253, see further Huyse 1999, II: 21 and Chaumont 1975, 101.

20 Huyse 1999, I: 28; here again the passage is taken from the Parthian version, since the Middle Persian one presents a large lacuna. 
The Caucasian provinces listed in $\S 2$ cover the entire Caucasian region, together with neighbouring lands. From Azerbaijan to the area to the South of the Caspian sea (Padišxwār ). It includes, Amenia, Iberia, Albania, the land of Sīgān, possibly to be identified with the Armenian principality of Siwnik' near today's Naxčawan, ${ }^{21}$ the region of Balāsagān north of the Kura'22 and up to the Caucasian Gates.

Kerdīr's inscriptions mention Armenia among the non-Iranian lands (Anērānšahr) conquered by the army of the King of Kings. The list includes some of the toponyms listed by Šābuhr:

§ 15. u-m pad-iz Anērānšahr ādur ud mowmard cē pad šahr ì Anērān būd kū asp ud mard ̄̌ šāhān šāh rasīd - Andiyōk šahrestān ud Sūriyā šahr ud cē abar Sūriyā nahang, *Tersōs šahrestān ud Kilikiyā šahr ud cē abar Kilikiyā nahang, Kēsariyā šahrestān ud Kapōdakiyā šahr ud cē abar Kapōdakiyā nahang tā frāz $\bar{o}$ *Grāykiyā šahr ud Arman šahr ud Wiruzān ud *Alān ud Balāsagān tā frāz ō Alānān dar Šābuhr šāhān šāh pad asp ud mard $\bar{\imath}$ xwēš zad u-š wardag ud ādursōxt ud awērān kerd...

$\S 15$. "And also the land of Aneran, the fires and mages which were in the land of Aneran where the horses and men of the king of king reached - the city of Antioch and the land of Syria and that which is attached to the province of Syria, the city of Tarsos and the land of Cilicia and what is attached to the province of Cilicia, the city of Caesarea and the land of Cappadocia and what is attached to the province of Cappadocia, up to the land of Graecia (= Pontus) and the land of Armenia and Iberia (= Georgia) and Albania and Balasagan up to the gate of the Alans, Shapur, King of Kings with his horses and men conquered them all and he took booty and burned and laid them waste ... .

Comparing the list of regions belonging to the Empire according to Šābuhr's inscription with the list of non-Iranian countries in Kerdīr's inscription is quite informing, since it clearly shows that the Caucasian countries conquered by Šābuhr in 252/3 not considered part of $\bar{E} r \bar{a} n s ̌ a h r$ by the high priest, were counted among the possessions of the Sasanian Crown, thus justifying the title of $\breve{S} \bar{a} h \bar{a} n$ Š $\bar{a} h \bar{E} r \bar{a} n$ ud Anerrān carried by Šābuhr in this and in other inscriptions, though not on his coins, ${ }^{24}$ while the same is not true for the lands belonging to Anatolia that are not listed in ŠKZ among royal dominions. Interestingly, the land of Sīgān, included among the countries of the Caucasian region by Šābuhr, is not present in Kerdīr's list.

21 Thus following Henning 1947-1948, 54 ${ }^{1}$ and 1952, 512, against Maricq (in Honigmann - Maricq 1953, 63-80, 172-174 and 178), on the whole issue see Huyse 1999, II: 23-24.

22 See Huyse 1999, II: 24-25, with reference to Kettenhofen 1995, 13-16.

23 KKZ 11-12 = KNRm 36-39 = KSM 17-18, text and translation according to MacKenzie 1989, 43-44, 58, compare Gignoux 1991, 62, 71.

24 This topic has been discussed in great detail by Alram (in Alram - Gyselen 2003, 190), who correctly does not follow Göbl $\left(1965,288^{16}\right)$ in considering it a proof to assign the inscription to the reign of Ohrmazd I. See also Huyse 1999, I: 12. 


\section{Narseh, King of the Armenians}

The title Armenān Šăh "King of the Armenians" is attested both in the inscription of Šābuhr and in that of Narseh ${ }^{25}$ (see above), most interestingly it is also known from a coin dating from the reign of Yazdagerd I (399-421), which on the reverse carries an horned bust identified by the inscription Šābuhr wuzurg Armenān $\check{S} \bar{a} h .{ }^{26}$ From the point of view of historical reconstruction, this coin is quite remarkable, since it attests that the title wuzurg Armenān Šāh, carried by the future king Ohrmazd in Šābuhr's inscription, but not by Narseh in his own text, where he defined himself only Armenān $\breve{S} a \bar{h},{ }^{27}$ was still being used in the early 5 th century.

In Šăbuhr's inscription at the Ka'aba-i Zartusht, the title of "King of the Armenians" is borne by the heir apparent to the throne, Ohrmazd-Ardašīr, who at the moment of his father's death was to rise to the Sasanian throne. Two passages of ŠKZ mention the names and titles of the future King of Kings Ohrmazd and those of Narseh, who was bound to conquer the crown after the Wahramid intermezzo.

The names of these two kings come forth once in a list containing the names of the fires established by Šābuhr for the main members of the dynasty, listing only some of his sons, presumably those who could claim rights of royal succession:

§ 33. ud èdar-iz [pad nib]išt [nišāyēm: ādur 1] Husraw-Šābuhr nām, pad amā ruwān ud pannām; $\bar{a} d u r 1$ Husraw-Ādur-Anāhìd nām, pad Ādur-Anāh[īd, bāmbišnān bambišn ī amā duxt] ruwān ud pannām ; [ādur 1] Husraw-Ohrmezd-Ardaš̄ir nām, pad Ohrmezd-Ardaš̄ir, wuzurg šāh Arminān $\bar{\imath}$ amā pusar ruwān ud pannām; $\S 34$ any Ādur 1 Husraw-Šābuhr nām, pad Šābuhr ī Mēšān šāh ī amā pusar ruwān ud pannām; ādur 1 Husraw-Narseh nām, pad ēr mazdēsn Narseh, šāh Hind, Sagestān ud Türestān tā draya damb [ī amā pusar], ruwān ud pannām.

$\S$ 33. Und auch hier, auf (= mittels) d(ies)er Inschrift, gründeten Wir: ein Feuerheligtum, HusrawŠābuhr ('Ruhmreich ist Šābuhr) mit Namen, für Unsere Seele und (Unseren) Nachruhm; 1 Feuer (heiligtum), Husraw-Ādur-Anāhīd ('Ruhmreich ist Ādur-Anāhīd') mit Namen, für Seele und Nachruhm von Ādur-Anāhīd, der Königin von Königinnen, Unserer Tochter; 1 Feuer(heiligtum), Husraw-Ohrmezd-Ardašīr ('Ruhmreich ist Ohrmezd-Ardašīr') mit Namen, für Seele und Nachruhm von Ohrmezd-Ardašīr, dem Großkönig der Armenier, Unserem Sohn; § 34 ein anderes Feuer(heiligtum), Husraw-Šābuhr mit Namen, für Seele und Nachruhm von Šābuhr, dem König von Mēšān, Unserem Sohn; 1 Feuer(heiligtum) Husraw-Narseh ('Ruhmreich ist Narseh') mit Namen, für Seele und Nachruhm des Ariers, des Mazdā-verherenden Narseh, des Königs von Hind(estān) Sagestān und Tūrān bis ans Meeresufer, Unseres Sohnes. ${ }^{28}$

25 In his 1952 paper identifying Hāyān $\bar{\imath} N \bar{i} k \bar{a} t \bar{o} r$ with Syr. Nìqātōo-Āwānā near Jalūlā at the junction of river Alwand with the Diyala, Henning proposed to interpret wuzurg Armenān šăh, which he inaccurately assigned to Narseh, as "King of Great Armenia" rather than "Great king of Armenia," see already Humbach Skjærvø 1979-1983, 3.2, 10.

26 Schindel 2014, note 404 and Gyselen 2019, 44, who writes about a second coin belonging to the Johnston collection.

27 However, this may well be due to the narrative context, where Narseh talks of himself both as King of the Armenians, likely referring to his past office, and King of Kings.

28 Huyse 1999, I: 46-47, taken from the Middle Persian version. On Ohrmezd I, Wahrām I and Narseh, see further Huyse 1999, II: 108-110, who briefly discusses the succession to the Sasanian throne. 
The second list presents the offerings intended for the sacrifices for the souls of a larger number of members of the dynasty. Here the sons of Šābuhr are seemingly listed according to age:

§ 36. pad amā ruwān rōz ō rōz akbrīd 1, nān g(rīw) 1 h(ōfan) 5, may p(ās) 4; pad Sāsān ī Xwadāy, ud

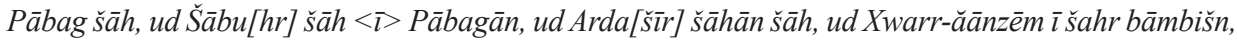
ud Ādur-Anāhīd bāmbišnān bāmbišn, ud Dēnag bāmbišn, ud Warhrān $<\bar{\imath}>$ Gēlān šāh, $<u d>$ Šābuhr i Mēšān šāhh, § 37 ud Ohrmezd-Ardašìr ī wuzurg šāh Arminān ud Narseh ī Sagān šāh, ud Šābuhrduxtag ì Sagān bāmbišn, ud Narsehduxt ī Sagān bānūg, ud Čašmag ì bānūg, ud Pērōz ̄̄ wispuhr, ud *Murrōd [ī bānūg ī] Šābuhr šāhān šāh mād, ud Narseh ī wispuhr, ud Rōdduxt ī dux̌̌ ̄ inō̄šag duxt, ud Warāzduxt $\bar{\imath}$ Xwarr-ăānzēm duxt, $\S 38<u d>$ Staxryād bāmbišn, ud Hormezdag ì Arminān šāh pus ..."

§ 36. für Unsere Seele Tag für Tag 1 Lamm, 1 grīw und 5 hōfan Brot, 4 pās Wein; für die Seelen (von) Sāsān, dem Herrn; und Pābag dem König; und Šābuhr, dem König, dem Sohn von Pābag; und Ardašīî, dem König der Könige; und Xwarrānzēm, der Königin des Reiches; und Ādur-Anāhīd, der Königin der Königinnen; und Dēnag, der Königin; und Wahrām, dem König von Gēlan; und Šābuhr, dem König von Mēšān; §37 und Ohrmezd-Ardašīr, dem Großkönig der Armenier; und Narseh, dem König der Saken; und Šābuhrduxtag, der Königin der Saken; und Narsehduxt, der Herrin der Saken; und Časmag, der Herrin; und Pērōz, dem Prinzen; und *Murrōd, der Herrin, der Mutter des Šābuhr, des König der Könige und Narseh, dem Prinzen; und Rōdduxt, der Prinzessin, der Tochter von Anōšag; und Warānduxt, der Tochter von Xwarrānzēm; § $38<\mathrm{ud}>$ Staxryād bāmbišn ud Hormezdag 1 Arminān šāh pus . . . ${ }^{29}$

Going back to the Paikuli inscription, the sentence found in $\S 13 *_{\text {sāsannagān ud }}$ hamāg šahr mardom armenān šāh mahist ud pahlom should be compared with $\S 88$ ašma bay mahišt ud pahlom "Your Majesty is the greatest and foremost" and may well find a parallel in the statement reported by Agathangelos stating that the King of Armenia was second in the kingdom of the Persians, ${ }^{30}$ otherwise it could plainly refer to the qualities held by Narseh personally, as already suggested by P. O. Skjærvø. ${ }^{31}$

\section{Anāhīd, the Paikuli Inscription and Armenia}

As we have seen above, the name of the goddess Anāhīd comes forth twice in the Paikuli inscription, once as one of the king's protective deities when Narseh left Armenia for Ërānšahr and once in the dedicatory name of the monument itself. Notably, Anāhīd is not mentioned in any other Sasanian royal inscription, though later sources inform us of the importance her cult had for the dynasty. On the contrary, the name of this divinity is

29 Huyse 1999, I: 49-51, taken from the Middle Persian version.

30 Agathangelos, 1.18: “... Khosrow king of the Armenians - who was second in the kingdom of the Persians, for whoever was king of the Armenians had second rank in the Persian kingdom ..." (Thomson 1976, 35; see Frye 1956, 318), substantially confirmed by P'austos that stated that the king of Armenia had the right to sit at desk of the King of Kings at royal banquets (Chaumont, 1987, 429). The passage describes the moment in which King Khosrow of Armenia was informed about Ardawān's defeat at the hand of Ardašīr therefore it refers to the situation at the end of the Parthian period, but the evidence of ŠKZ shows that the same was trueat least formally - for the early Sasanian dynasty.

31 Humbach - Skjærvø 1979-1983, 3.2, 16. 
mentioned by Kerdīr in his inscriptions in a passage saying that at the peak of his power, the magus became responsible for the fire of Anāhīd at Staxr:

§ 9. ud pas kū Wahrām šāhān šăh $\bar{\imath}$ Šābuhragān ō bayan gāh šud ud Wahrām šāhānn šāh $\bar{\imath}$ Wahrāmagān, ī andar šahr rād ud rāst ud mihrabān ud hugar ud kerbakkar, pad šahr ēstèd ud pad dōšāramīh ī Ohrmezd ud yazadān ud xwēšs ruwān rāy ān-im andar šahr abardar gāh ud padixšar kunēd u-m gāh ud padixšar $\bar{\imath}$ wuzurgān dahēd u-m pad dar ud šahr ō šahr, gyāg ō gyāg, hāmšahr pad kerdagān ì yazadān pādixšādar ud kāmgāardar kunēd kū čiyōn ahy būd hēm §10 u-m hāmšahr

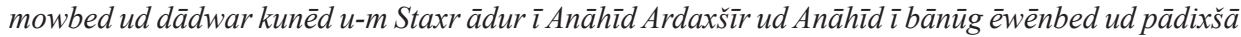
kunèd u-m kunēd nām 'Kerdīr ì bōxt-ruwān-Wahrām ì Ohrmezd mowbed'.

$\S 9$. And after Bahram, king of kings, son of Bahram, who in the empire (is) generous and righteous and kind and beneficent and altruistic, established himself in the kingdom, for love of Ohrmezd and the gods and (for) his own soul he made for me in the empire a higher position and honour, and gave me the position and honour of the magnates, and made me at court and from province to province, place to place, throughout the empire in (the matter of) the rites of the gods (yet) more authoritative and absolute than I was before. $\S 10$ And he made me Mobed and judge of the whole empire. And he made me director and authority over the fire of Anahid-Ardashir and Anahid the Lady (in) Stakhr. And he named me 'Kerdir, souls-saver of Bahram, Mobed of Ohrmezd' ${ }^{32}$

The Middle Persian form of the theonym Anāhitā comes forth in a number of theophoric names: Anāhīd, Ādur-Anāhīd, Bōxt-Anāhīd, Burz-Anāhīd, Gušnāsp-Anāhīd, Anāhīd-panāh, Anāhīd-rāz, Anāhīd-sudān, Raxš-Mihr-Anāhīd, Anāhīd-xrad. ${ }^{33}$ All these names occur on documents, mainly seals, but also a letter, dating to the late Sasanian period showing that the deity was still venerated in the 6th and 7 th centuries, and that her cult continued until the end of the dynasty, thus substantially confirming the iconographic evidence that though not abundant, covers a long period of time.

The female figure standing behind the sovereign in the bas-relief chiselled in the higher register of the larger grotto at Taq-i Bustan has been convincingly identified with the goddess Anāhīd, since she holds in her hand a pitcher pouring water. Most scholars date this relief to the reign of Husraw II, however considering the possibility that its style may have been influenced by western schools of carving, a date in the 5 th century may be more appropriate (Fig. 1). ${ }^{34}$ The only surviving bas-relief that may be attributed with certainty to Narseh ${ }^{35}$ is found in Naqsh-i Rustam (Fig. 2) and depicts the king standing in front of a female individual, who has been identified either with the king's wife, Šābuhrduxtag, or with Anāhīd. Personally, I find argumentations in favour of assigning the relief to Anāhīd convincing, ${ }^{36}$ even more so considering the role played by this deity in Narseh's inscription at Paikuli. The two bas-reliefs are radically different one from the other. At Taq-i Bustan the goddess is less feminine and more majestic, while at Naqsh-i

32 MacKenzie 1989, 41-42, 54 and 58; cf. Gignoux 1991, 58-59, 68-69. On the rendering of Kerdīr's title under Wahrām opinions differ, Gignoux following Grenet 1990, 91, prefers to translate "Kirdīr, mowbed du bienheureux Vahrām, et d'Ohrmazd." In my opinion bōxt-ruwān-Wahrām can be compared to pērōzAnāhìd-Narseh, the name of the Paikuli monument; see further note 4.

33 Gignoux 1986; Gignoux 2003.

34 Callieri 2014, 155-159.

35 Narseh usurped a bas-relief of Wahrām I in Bishapur, substituting his name for that of his elder brother, see MacKenzie 1981, fig. 1-2, pl. 15.

36 See Shenkar 2014, 70-73; and now with fuller details Tanabe 2018, with earlier bibliography. 
Rustam her womanliness is more evident, underlined as it is by the folds of her dress. The crowns are also different one from the other, since the deity dons an arcade crown in Taq-i Bustan, while the mural crown worn by Anāhīd in Naqsh-i Rustam is quite similar to the one attested on a female bust represented isolated below the great relief of Šābuhr I6 at Darabgird ${ }^{37}$ (Fig. 3), which is therefore likely to be a third representation of the goddess. ${ }^{38}$ The Naqsh-i Rustam bas-relief was made after Narseh's defeat at the hand of Galerius that obliged him to accept the treaty of Nisibis. ${ }^{39}$

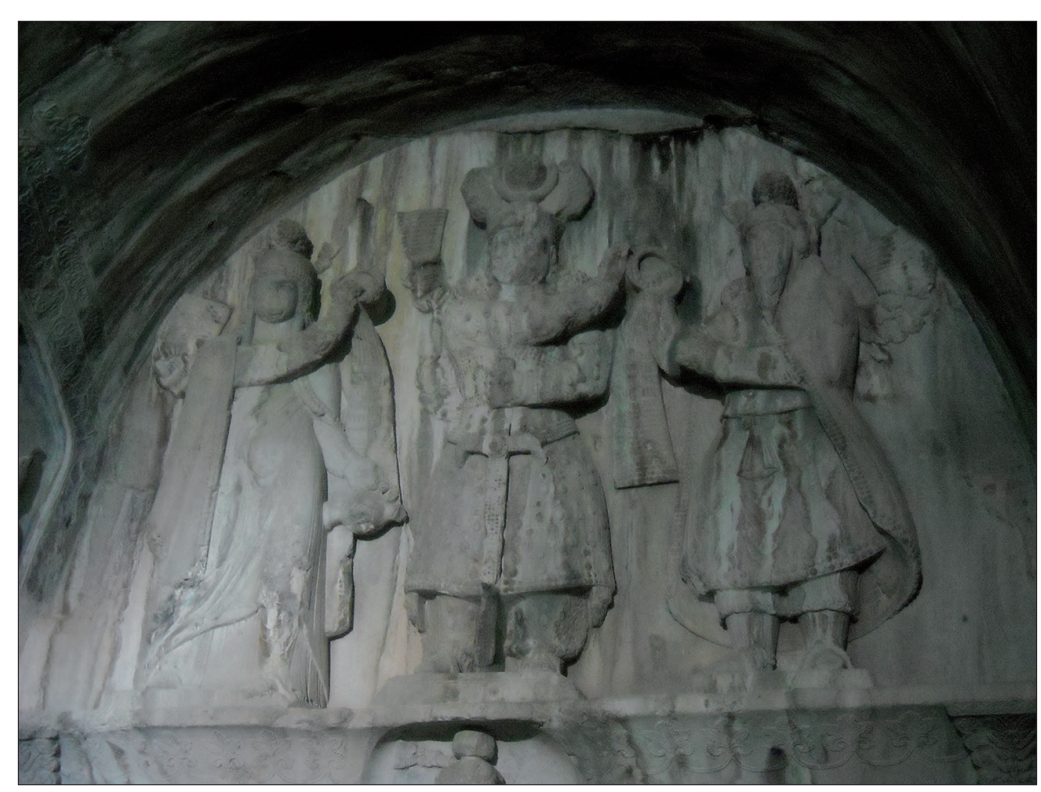

Fig. 1.

37 This relief has been variously dated to the reigns of Ardašīr or Šābuhr I, see the detailed discussion in Meyer 1990, 263-281.

38 See further Tanabe 2018, 13 and Levit-Tawil 1992a. Though some of her speculation may be a bit too far-fetched, the latter author correctly underlines the influence that Narseh's stay in Armenia had on this sovereign's reverence for the goddess (loc. cit. 217-220) and mentions a stucco bust from palace I of Kish (loc. cit. 204-205), which could likely be assigned to Anāhīd. See also Levit-Tawil 1992b, dating on shaky grounds the main relief to the last years of Ardašìr's reign (loc. cit. 179 et passim).

39 Tanabe 2018, 10; 18-20, with reference to Canepa 2009, 84 and Weber 2012, 224-230. For a detailed discussion of Anāhitā's attire in Yašt 5 see Andrés-Toledo 2017. Some peculiarities contained in the description (e.g. Yt. 5.123, where she is described as "a beautiful, very powerful, well-formed, high and right-girded noble (maid) of rich appearance, wearing a pleasing cloak of much shorn (wool), golden" loc. cit., 181) do not contradict her representation in Sasanian art and correspond to her being described by Agathangelos as the "golden mother" goddess (Thomson 1976, 347), whose statues are made of gold (Thomson 1976, 327), though the same does not necessarily prove true for the passages where her costume is described in more details. 


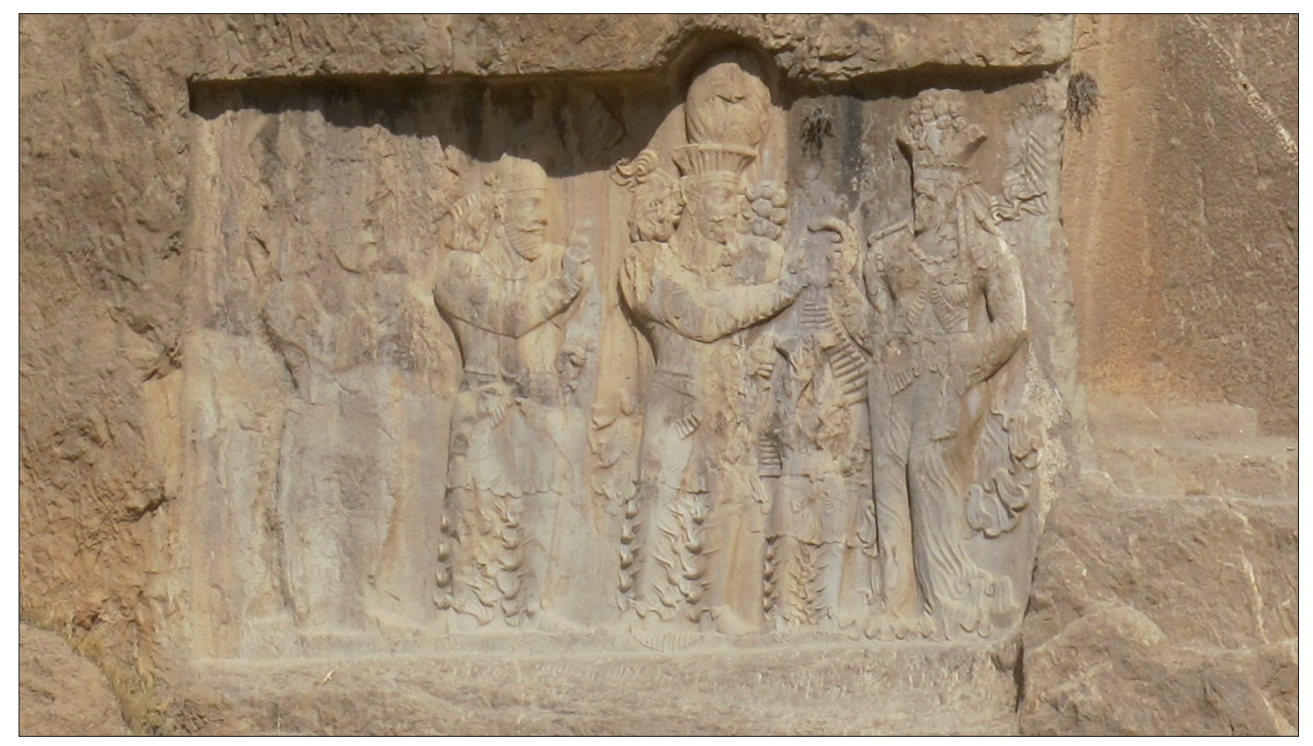

Fig. 2.

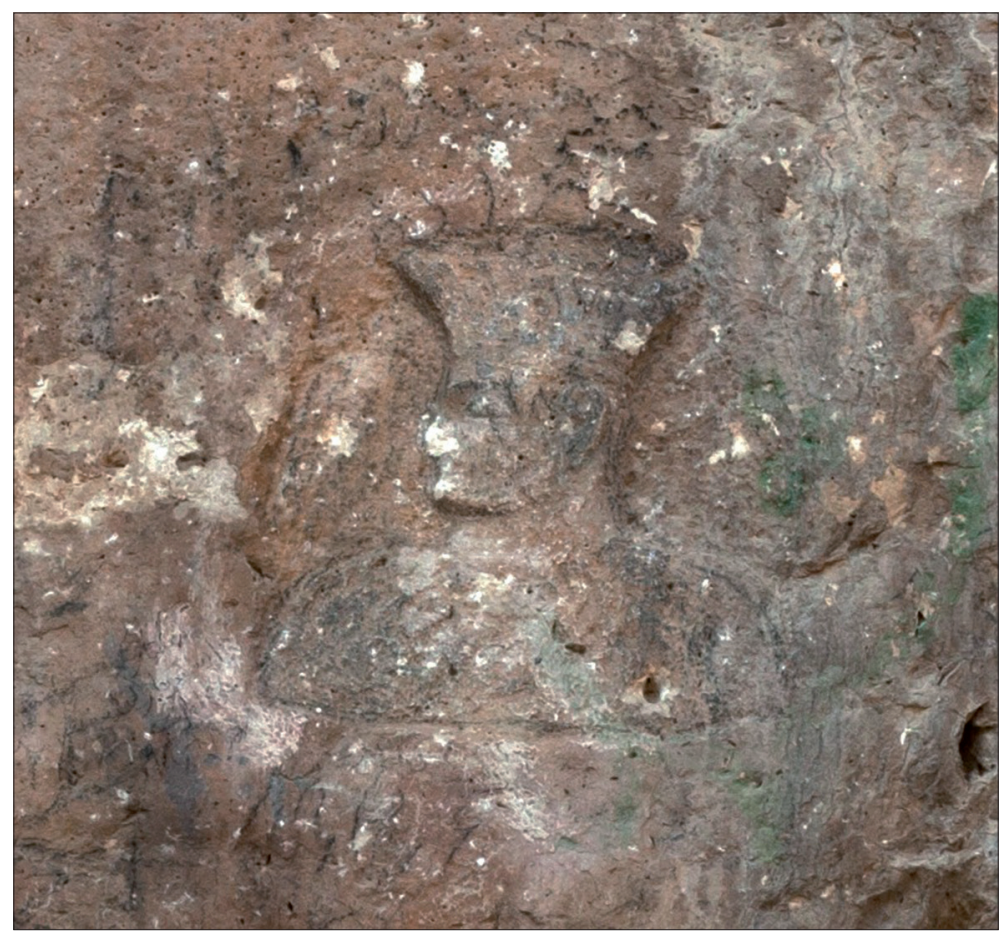

Fig. 3. 
Female figures are found on the coinage of Ohrmazd I and Wahram II. Ohrmazd I's drachma type $\operatorname{Ia}(1) 1(1)^{40}$ displays on the reverse the fire altar flanked by two characters, a male on the left, a female on the right, both holding in their hands a long object probably to be identified with a barsom. ${ }^{41}$ The female wears a mural crown and has been identified either with Anāhīd or with the xwarrah. Gyselen suggests a possible identification with the Roman Tyché, Fortuna, represented on some coins with a mural crown. This leads her to proposing a possible "plural" interpretation: "Tyché, Fortuna, xwarrah, queen. ${ }^{42}$ Does this rule out an identification with Anāhīd? Quite to the contrary, since Mary Boyce has shown that Av.

Anāhitā has incorporated some of the characteristic traits of another chariot-riding deity, companion to Mithra, the goddess Aș̣i, ${ }^{43}$ who is the divinity of reward ${ }^{44}$ and plays a role in defining Zoroaster's earthly destiny. ${ }^{45}$ Therefore, maintaining Gyselen's suggestion that the numismatic iconography should be open to a plurality of readings, the divinity represented on the reverse of Ohrmazd I's coins, may better represent at once Tyche/ Fortuna and Anāhitā/Aṣ̆i, rather than Tyche/Fortuna and the xwarrah. Be this as it may, her mural crown further identifies her with the female character found on Narseh's basrelief at Naqsh-e Rustam and below Šābuhr's crowning at Darabgird. ${ }^{46}$ On the contrary, the female character represented on the reverse of Wahrām II's types VIIa(1)/5a1a, 1b) VIIa (6a/5a (2, 2a), VIIb(1)/5a(1a) and VIIc(1)/5b(1a) is less likely to be Anāhīd. ${ }^{47}$ Looking at Kushano-Sasanian copper coinage as presented by Sinisi (2015) and by Shenkar, ${ }^{48}$ coins bearing on the reverse a depiction of Anāhīd were minted under Ardashir 2 and $1^{49}$ probably dating to the $290 \mathrm{~s},{ }^{50}$ and, with a different crown, under Ohrmazd 2 (Sinisi 2015, 210). The legend 'n'hyd MROTA /Anāhìd banūg/ is clearly legible on Ardašīr 2 coins, identifying the deity wearing a mural crown characterised by crenelated battlements with Anāhīd the Lady. ${ }^{51}$ Ohrmazd 2's issues show a different iconography that needs not be discussed here, and the goddess wears a crown with the arcade motif inaugurated by Narseh's first crown type, ${ }^{52}$ which is found also on Anāhīd's crown at Taq-i Bustan. As

40 Alram - Gyselen 2012, 128.

${ }^{41}$ Cf. Yt. 5.127, where Anāhitā is said to be bā $\delta a$. yaAa.mąm. barzsmō.zasta "with the barzsman twigs in her hands as usual" (Andrés-Toledo 2017, 181-182).

42 Alram - Gyselen 2012, 141-143; see also Gyselen 2010, 78-79.

43 Boyce 1975, 72-73; Boyce 1982, 203; Boyce 1985, 1004.

44 Schlerath - Skjærvø 1987, 750-751.

45 Kellens 1999, 463.

46 Levit-Tawil 1992a, 221-222 compares the iconography of Narseh's relief at Naqsh-i Rustam, showing the emperor and the goddess Anāhīd, with representations of Roman emperors together with Victoria Romana, which may well be another possible interpretation of the iconographic motif.

47 Alram - Gyselen 2012, 250-252 and 275, contra Shenkar 2014, 70. Wahrām II is often depicted on his coinage together with the queen and/or the crown prince (Alram - Gyselen 2012, 207-209), similarly considering overall iconography and the numismatic evidence, the female characters present on some of his bas-reliefs (for a bird eye view, see Shahbazi 1989 with reference to Herrmann 1970) and on the disputed one at Barm-i Dilak near Shiraz (Vanden Berghe 1989), are less likely to be identified with divine beings.

48 Shenkar 2014, 76-77.

49 Thus following Sinisi 2015's numbering of kings.

50 Sinisi 2015, 203-204.

51 Interestingly the same sequence, Anāhìd Banūg, is found also in the Paikuli inscription.

52 Sinisi 2015, 210, with reference to Alram - Gyselen 2012, 295-300. 
readily recognized by Sinisi, ${ }^{53}$ the iconography attested on the coins of Ardashir 2 and 1, confirms the identification of the female character on Narseh's bas-relief at Naqsh-i Rustam and the one at Darabgird with Anāhīd, as well as the identification of this deity on Ohrmazd I's coinage. Moreover, in Yašt 5 the deity wears a crown "with hundred strayh $\bar{a}$, golden, with eight towers", ${ }^{54}$ also pointing to a similar headdress.

Summing up, other than the Kushano-Sasanian coins dating from the 290s, we have representations of Anāhīd with a mural crown under Ohrmazd I (270/72-273, coins), Narseh (293-302, Naqsh-i Rustam) and probably already under Sābuhr I (239/40 270/72, Darabgird). The iconography found on the coins of Wahrām II (276-293) does not allow one to identify the female character represented on the reverse with the great goddess, though this possibility cannot be entirely excluded. Therefore, as things stand today, we may conjecture that Anāhīd was particularly dear to the sovereigns listed in Šābuhr's inscription in the list of the main members of the family, and perhaps to Šābuhr I himself showing that this specific lineage showed a manifest devotion to the great goddess. The same cannot be said for the Wahramids, though it cannot be excluded with absolute certainty.

According to some of the authors whose narration derives from the Xwadāy-namag ${ }^{55}$ before ascending the imperial throne the Sasanians already were the guardians of the temple of Anāhīd at Stakhr ${ }^{56}$ an honour that Wahrām II later conferred upon the mage Kerdīr. Islamic historiographers further report that the worship of Anāhīd was promoted and supported by Ardašīr and that Šābuhr named one of his daughters, bound to be his queen, Ādur-Anāhīd, showing his own deference for the goddess. This tradition must have continued, in forms that we cannot trace with confidence, till the end of the dynasty considering that the last of the Sasanian emperors, Yazdegard III, was raised in the ancestral temple of Stakhr. ${ }^{57}$

Combining textual evidence with what we know from iconography, among early Sasanian kings Narseh was the one who most certainly felt a marked devotion to the goddess of waters, whom he mentions twice in his inscriptions and depicts in his investiture bas-relief at Naqsh-i Rustam. This devotion may either be interpreted as going back to the oldest roots of family history in Stakhr, where Narseh's ancestors had long been the caretakers of the temple of Anāhīd or as a trait acquired in Armenia, where the cult of Anaitis was particularly strong. ${ }^{58}$ More probably it was a combination of the two, stressed by Narseh in contrast to the Wahramid sovereigns and to Wahrām II's decision to "assign authority over the fire of Anahid-Ardashir and Anahid the Lady (in) Stakhr" to Kerdīr, the Mobed of Ohrmazd. ${ }^{59}$ The strong rivalry between Narseh and Wahrām I is shown by the former's decision to counterfeit the latter's bas-relief at Bishapur, denying de facto his

53 Sinisi 2015, 215-216; following Shenkar 2013.

54 Yt. 5.128 satō strayhąm zaranaēnīm ašta.kā̄ždąm (cf. Andrés-Toledo 2017, 182).

55 For a reassessment of the Xwadāy-nāmag tradition, see recently Hämeen-Antilla 2018.

56 Chaumont 1958, 155-156.

57 On the worship of Anāhīd under the early Sasanians see Chaumont 1958; on the cult and its diffusion, see Chaumont 1985.

58 Shenkar 2014, 73 .

59 Chaumont $(1958,163-164,169-173 ; 1965,171-173)$ has rightly recognized the importance of this passage of Kerdīr's inscriptions, already postulating that Wahrām II had renounced his ancestral rights, while later sovereigns may have reclaimed them. 
right to the throne. Quite likely he held the same feelings against his successor, Wahrām II, under whose rule Kerdīr's power reached its Zenit, usurping - this at least might have been Narseh's feeling - even the hereditary honour of serving Anāhīd in the ancestral sanctuary.

The importance Anāhīd had in the lands of Anatolia is well known ${ }^{60}$ and so is the importance of the goddess in Armenia, underlined with plenty of data by many an author. ${ }^{61}$ Many were the temples dedicated to this deity in the Caucasian country, most important of which was Erēz in the region of Acilisene, ${ }^{62}$ where according to the Greek version of Agathangelos the Armenian kings celebrated the annual feast in honour of Anāhīd. ${ }^{63}$ a well-known episode of the life of St. Gregorious narrated by Agathangelos witnesses the deep reverence that Tiridates felt for Anāhīd before being converted to Christianity:

48. In the first year of the reign of Trdat in Greater Armenia they went to the province of Ekeleats to the village of Erēz, to the temple of Anahit in order to sacrifice there. And when they had completed this unworthy deed, they went down and encamped on the bank of the river called Gayl. 49. When he had entered his tent and sat down to table, and when they had drunk well the king ordered Gregory to present to the altar of Anahit's statue offerings of crowns and thick branches of trees. But he did not agree to serve the worship of the gods. 50. Then the king began to speak with Gregory and said: "You have come and joined us as a foreigner and a stranger. How then are you able to worship that God which I do not worship?" And he ordered him to be imprisoned for that day. The next morning, he commanded that they bring Gregory before the king. 51. The king began to speak with Gregory and said: "It is this many years that I know you and you have served me faithfully with all your strength. I have been very satisfied with your labors and I intended to reward you. Why then do you not do my will?" 52. Gregory replied and said: "It is commanded by god that servants 'should be obedient to their bodily lords' [Eph. 6.5], as is right and as you have borne witness to me that I have served you with all my strength. But it is not fitting to pay to any one else the honor and worship due to God. For he alone is the creator of heaven and of the angels, who glorify his majesty, and of earth and of men, who have been fashioned by him and whose duty is to worship him and to do his will; (as also should) everything else that is in them, in the sea and on land." 53. The king said: "Know that you have made useless the services that you have rendered to me and to which I am witness. Now, instead of the rewards which you should have received, I shall increase affliction upon you; and instead of honor, dishonor; instead of elevation to high rank, prison and bonds and death which removes all hope of life for men - unless you agree to offer worship to the gods, and especially to this great lady Anahit. She is the glory of our race and our savior, her all kings honor, especially the king of the Greeks. She is the mother of all virtues, benefactor of all human nature, and the offspring of the great and noble Aramazd. ${ }^{64}$

At the end of his dispute with Gregory, the king concluded by saying:

68. . . how often have I given you warning and commands not to repeat in my presence these compositions of fabulous stories which you have pieced together and learned up and which is unfitting for you to tell? So I have spared you, because of your services, in order that you might come to the

60 Boyce - Grenet 1991, 197-253.

61 I.a. Chaumont 1965; Russel 1987, 235-260. See however also Brosius 1998, who for post-Achaemenid times prefers to speak of an "persianisation of the cult of Artemis," rather than a "hellenisation of the cult of Anahita" (loc. cit., 238).

62 Chaumont 1965, 173-176; Chaumont 1985; Russel, loc. cit. et passim.

63 Chaumont 1965, 174 and note 54 with reference to Garitte 1946, 78.

64 Thomson 1976, 61-65. 
right path and worship the gods, whose honor you have slighted by calling someone else creator. And those who are truly creator you insult, calling lifeless and mute the great Anahit, who gives life and fertility to our land of Armenia, and with her the great and noble Aramazd, the creator of heaven and earth, and with him the other gods. And you have gone so far as to insult us as well, daring to call us horses and mules. Because you have multiplied all these insults - even to calling us animals - now I shall cast you into torments and I shall place a bridle on your cheeks... ${ }^{65}$

Notwithstanding Thomson's critical position about the value of Agathangelos' narration, ${ }^{66}$ and taken together with the other passages reporting forms of worship of Anāhīd in Armenia, this episode clearly shows that the cult of the "Golden Mother" was particularly dear to the sovereigns of this mountainous land, just as it was to Narseh. ${ }^{67}$

\section{Conclusions}

This short presentation left us with more open questions than answers. What was the extent of the Armenia over which Narseh ruled? And what exactly was the situation of this province after the peace treaty between Diocletian and Wahrām II? Which was the role played by Tīrdād?

The inscription of Paikuli tells us that upon the invitation of the dignitaries who opposed Wahrām III, Narseh came south from Armenia following the road that went across the Zagros mountains, from Azerbaijan to Asūrestān. Furthermore, we know that he considered his position as King of Armenians important enough in Sasanian hierarchy for him to mention it several times in the Paikuli inscription, notwithstanding the fact that at the time of writing he could already boast the much more impressive title of King of Kings. We are not in the position to identify with certainty the Tīrdād mentioned in Narseh's inscription, should he really be a member of the Armenian royal house, a son of Khusraw, this would show that a part of Armenia maintained some sort of independence. Nonetheless, the part of Armenia ruled by Narseh must have been by far the greater one, important enough to justify its being considered worthy of being the fief of the crown prince.

65 Thomson 1976, 77.

66 Thomson 1985, 608: "The pagan deities and their cult sites mentioned by Agathangelos have attracted attention, but little reliable information can be gleaned from this hagiographical work. Indeed, the description of Anahit's cult at Erez ( $\mathrm{Aa}$ 48-49) bears no relation to the account in Strabo (11.14.16) but is based on a combination of passages from the Books of Maccabees unrelated to Anahit. She is described by Agathangelos as the special protectress of the Armenian people, source of life and fertility, and as the "golden mother" or "golden-born goddess" from the wealth of her sanctuaries. At Ashtishat Gregory's first church was built on the site of a "trinity" of cults: Anahit, Aramazd (Mid. Pers. Ohrmazd, father of all the gods, creator of heaven and earth), and Vahagn (Mid. Pers. Wahrām), called vishapak'at ("who handles dragons"). Other deities mentioned by Agathangelos are Asțłik ("little star," spouse of Vahagn), Tir (called "interpreter of dreams"), Name (Nanaia), Barshamin, and Mihr."

67 Chaumont (1965, 176-178) suggests a possible Sasanian influence on Armenian religion at the time of Šābuhr I and Ohrmazd I, an influence which this scholar believed to have brought the cult of Anāhīd in line with the more orthodox Zoroastrianism of the Iranian highlands. However, this needs not be the case and the contraposition might well have been between a less conventional Zoroastrianism own to the early Sasanians and a more "orthodox" version of the same religion advocated by Kerdīr. 
Why did Narseh chose to underline his personal devotion to the goddess of waters both in script and image? Anāhīd plays an important role in the Paikuli inscription and in the bas-reliefs that this sovereign ordered to carve in Naqsh-i Rustam, and we have evidence that she was equally revered under the first three kings of the Sasanian dynasty. Similarly, together with Ohrmazd, Anāhīd was the favorite deity of the Armenian ruling house. Did Narseh knowingly choose to emphasize the role of this deity on the one hand to highlight continuity with his grandfather, his father and his brother, and on the other to please his Armenian supporters, as well as other traditionalists? Finally, did Wahrām II's decision to assign authority over the Fire of Anāhīd the Lady to Kerdīr, a staunch supporter of "orthodox" Mazdeism play a role in Narseh's choice? Was he consciously contrasting Kerdīr's “orthodox" and fanatic religious doctrine as well as the crown's loss of control over religion?

\section{BIBLIOGRAPHY}

Alram, M., Gyselen, R. (2003), Ardashir I.-Shapur I, (Sylloge Nummorum Sasanidarum Paris-BerlinWien, vol. 1), Wien.

Alram, M., Gyselen R. (2012), Ohrmazd I.-Ohramzd II, (Sylloge Nummorum Sasanidarum ParisBerlin-Wien, vol. 2), Wien.

Andrés-Toledo, M. Á. (2017), The Description of Anāhitā's attire in the Yašt 5, in: C. Brøns, M.-L. Nosch (eds.), Textiles and Cult in the Ancient Mediterranean, Oxford-Philadelphia: 179-188.

Boyce, M. (1975), a History of Zoroastrianism, vol. 1, Leiden-Köln.

Boyce, M. (1982), a History of Zoroastrianism, vol. 2, Leiden-Köln.

Boyce, M. (1985), Anāhīd i. Ardwīsūr Anāhīd, EI 1: 1003-1005.

Boyce, M., Grenet, F. (1991), a History of Zoroastrianism, vol. 3, Leiden-Köln.

Brosius, M. (1998), Artemis Persike and Artemis Anaitis, in: M. Brosius, a Kuhrt (eds.), Studies in Persian History: Essays in Memory of David M. Lewis, (Achaemenid History - 11), Leiden: 227-238.

Canepa, M. P. (2009), The Two Eyes of the Earth: Art and Ritual of Kingship between Rome and Sasanian Iran, Berkeley-Los Angeles-London.

Cereti, C. G., Terribili, G. (2012), The Paikuli Monument, in: M. Alram, R. Gyselen, Ohrmazd I.Ohr-mzd II, (Sylloge Nummorum Sasanidarum Paris-Berlin-Wien, vol. 2), Wien: 74-87.

Cereti, C. G., Colliva, L., Terribili, G., (2019), Il monumento di Paikuli (Kurdistan, Iraq). Ricerche e nuove attività sul campo, Scienze dell'Antichità 25: 3-10.

Cereti, C. G., Terribili, G. (2014), The Middle Persian and Parthian Inscriptions on the Paikuli Tower: New Blocks and Preliminary Researches, Iranica Antiqua 49: 347-412.

Cereti, C. G., Terribili, G., Tilia, A. (2015), Pāikūl̄̄ in Its Geographical Context, in: A. Krasnowolska, R. Rusek-Kowalska (eds.), Studies on the Iranian World, vol. I: Before Islam, Kraków: 267-278.

Chaumont, M.-L. (1958), Le culte d'Anahita à Stakhr, Revue de l'histoire des religions 153: 154-175.

Chaumont, M.-L. (1965), Le culte de la déesse Anahita dans la religion des monarques d'Iran et de l'Arménie au Ier siècle de notre ére, Journal Asiatique 253: 167-181.

Chaumont, M.-L. (1968), Les grands rois sassanides de l'Arménie, Iranica Antiqua 8: 81-93.

Chaumont, M.-L. (1975), Etats vassaux dans l'Empire des premiers Sassanides, in: Monumentum H.S Nyberg, vol. I, (Acta Iranica - 4), Liège: 89-156, with an Addendum in vol. III (Acta Iranica - 6): 356. 
Chaumont, M.-L. (1985), Anāhīd iii: The Cult and Its Diffusion, EI 1: 1006-1009.

Chaumont, M.-L. (1987), Armenia and Iran, ii. The PreIslamic Period, EI 2: 418-438.

Frye, R. N. (1956), Notes on the Early Sassanian State and Church, in: Studi orientalistici in onore di Giorgio Levi della Vida, vol. 1, Roma: 314-335.

Garitte, C. (1946), Documents pour l'étude du libre d'Agathange, Città del Vaticano.

Garsoïan, N. (2003), Le "Guerrier des Seigneurs," Studia Iranica 32: 177-184.

Gignoux, Ph. (1986), Noms propres Sassanides en moyen-perse épigraphique, (Iranisches Personennamenbuch, vol. II.2), Wien.

Gignoux, Ph. (1991), Les quatre inscriptions du mage Kirdīr. Textes et concordances, (Studia Iranica, Cahier - 9), Paris.

Gignoux, Ph. (2003), Noms propres Sassanides en moyen-perse épigraphique. Supplément [19862001], (Iranisches Personennamenbuch, vol. II.3), Wien.

Göbl, R. (1965), Vāsiška, ein bisher unbekannter König der späteren Kušān, $A \ddot{O} A W$ 102: 283-300.

Grenet, F. (1990), Observations sur les titres de Kirdīr, Studia Iranica 19: 87-94.

Gyselen, R. (2010), Romans and Sasanians in the Third Century AD: Propaganda Warfare and Ambiguous Imagery, in: H. Börm, J. Wiesehöfer (eds.), Commutatio et Contentio. Studies in the Late Roman, Sasanian and Early Islamic Near East in Memory of Zeev Rubin, Düsseldorf: 71-89.

Gyselen, R. (2019), La Géographie administrative de l'Empire Sassanide. Les témoignages épigraphiques en moyen-perse, (Res Orientales - 25), Bures-sur-Yvette.

Hämeen-Antilla, J. (2018), Khwadāynāmag: The Middle Persian Book of Kings, Leiden-Boston.

Henning, W. B. (1947-1948), Two Manichaean Magical Texts, with an Excursus on the Parthian Ending èndēh, Bulletin of the School of Oriental and African Studies 12: 39-66. [= W. B. Henning, Selected Papers, vol. II, (Acta Iranica - 15), Leiden 1977: 273-300].

Henning, W. B. (1952), a Farewell to the Khagan of the Aq-Aqatärān, Bulletin of the School of Oriental and African Studies 14: 501-522. [= W. B. Henning, Selected Papers, vol. II, (Acta Iranica - 15), Leiden 1977: 387-408].

Herrmann, G. (1970), The Sculptures of Bahram II, Journal of the Royal Asiatic Society [= Studies in Honour of Sir Mortimer Wheeler] 102.2: 165-171.

Honigmann, E., Maricq, A. (1953), Recherches sur les Res Gestae Divi Saporis, Brussels.

Humbach, H., Skjærvø, P.O. (1979-1983), The Sassanian Inscription of Paikuli, 3 vols., Wiesbaden.

Huyse, Ph. (1999), Die dreisprachige Inschrift Šābuhrs I. an der Ka ba-I Zardušt (ŠKZ), (Corpus Inscriptionum Iranicarum III.I.I), 2 vols., London.

Kellens, J. (1999), Aṣ̆i ou le grand départ, Journal Asiatique 287.2: 457-464.

Kettenhofen, E. (1995), Tirdād und die Inschrift von Paikuli. Kritik der Quellen zur Geschichte Armeniens im späten 3. Und fruhen 4. Jh. N. Chr., Wiesbaden.

Levit-Tawil, D. (1992a), The Syncretistic Goddess Anahita in the Light of the Small Bas Relief of Darabgird: Her Imagery on Early Sasanian Rock Reliefs and Seals, Iranica Antiqua 27: 189-225.

Levit-Tawil, D. (1992b), The Sasanian Rock-Relief at Darabgird: A Re-evaluation, Journal of Near Eastern Studies 51: 161-180.

MacKenzie, D. N. (1981), The Inscription, in: G. Herrmann, D. N. Mackenzie, R. Howell, The Sasanian Rock Reliefs at Bishapur, part 2: Bishapur IV, Bahram II Receiving a Delegation; Bishapur V, The Investiture of Bahram I; Bishapur VI, The Enthroned King (Iranische Denkmäler, Lieferung 10, enthaltend Reihe 2, Iranische Felsreliefs F), Berlin: 14-17.

MacKenzie, D. N. (1989), Kerdir's Inscription, in: G. Herrmann, D. N. Mackenzie, R. Howell, The Sasanian Rock Reliefs at Naqsh-i Rustam: Naqsh-i Rustam 6, The Triumph of Shapur I (Iranische Denkmaler, Lieferung 13, enthaltend Reihe 2, Iranische Felsreliefs I), Berlin: 35-72.

Meyer, M. (1990), Die Felsbilder Shapurs I., JDAI 105: 237-302.

Russel, J. (1987), Zoroastrianism in Armenia, Harvard.

Schindel, N. (2014), The Schaaf Collection, (Sylloge Nummorum Sasanidarum Paris-Berlin-Wien), Wien.

Schlerath, B., Skjærvø, P. O. (1987), Aši, EI 2: 750-751. 
Shahbazi, A. Sh. (1989), Bahrām II, EI 3: 516-517.

Shenkar, M. (2013), a Goddess or a Queen? On the Interpretation of the Female Figure on the Relief of Narseh at Naqš-e Rostam [in Russian], in: Scripta Antiqua, Ancient History, Philology, Arts and Material Culture: Edward Rteveladze Felicitation Volume, Moscow: 614-634.

Shenkar, M. (2014), Intangible Spirits and Graven Images-The Iconography of Deities in the PreIslamic Iranian World, Leiden-Boston.

Sinisi, F. (2015), The Deities of the Kushano-Sasanian Coins, Electrum 22: 201-225.

Tanabe, K. (2018), Not the Queen Šābuhrduxtag but the Goddess Anāhitā: Identification of the Female Figure in the Investiture Scene of Narseh at Naqsh-i Rustam, Japan Society for Hellenistic-Islam Archaeological Studies 25: 9-26.

Thomson, R. W. (1976), Agathangelos, History of the Armenians, Albany, N.Y.

Thomson, R. W. (1985), Agathangelos, EI 1: 607-608.

Vanden Berghe, L. (1989), Barm-e Delak, EI 3: 805-807.

Weber, U. (2012), Narseh, König der Könige von Ērān und Anērān, Iranica Antiqua 47: 153-302. 